Far away and nearby: Holocaust remembrance and human rights education in Switzerland

Schlag, Thomas ; Wäckerlig, Oliver

DOI: https://doi.org/10.1007/s11125-010-9157-3

Posted at the Zurich Open Repository and Archive, University of Zurich ZORA URL: https://doi.org/10.5167/uzh-43699

Journal Article

Published Version

Originally published at:

Schlag, Thomas; Wäckerlig, Oliver (2010). Far away and nearby: Holocaust remembrance and human rights education in Switzerland. Prospects, 40(2):223-237.

DOI: https://doi.org/10.1007/s11125-010-9157-3 


\title{
Far away and nearby: Holocaust remembrance and human rights education in Switzerland
}

\author{
Thomas Schlag • Oliver Wäckerlig
}

Published online: 24 July 2010

(C) UNESCO IBE 2010

\begin{abstract}
The article considers how young people in Swiss schools are taught about the history and background of the Holocaust within the wider perspective of human rights education, as an important basis for education concerning democratic citizenship. Given the country's specific history, for decades the Holocaust was not a matter of great interest in Swiss schools, or a topic that pupils often learned about as a part of their own history. Recently, however, sensitivity about historical incidents and the processes of the Third Reich has increased. Holocaust education has also become more important in the context of Swiss state institutional policy and non-governmental initiatives and has also become an issue in schools. This article includes an overview of relevant Swiss history and the current political situation, and a review of Swiss educational policies and especially of activities related to Holocaust remembrance and human rights education.
\end{abstract}

Keywords Holocaust education · Human rights education - Remembrance · Switzerland

\section{Background of Swiss history and current political situation}

Reflections on Holocaust education for the future must consider the context within which Holocaust education and education for democratic citizenship take place, including the actual organisational framework and political institutions that provide such educational work. Therefore, we begin with some general remarks on the political setting.

Between 1933 and 1945, Switzerland played the role of a so-called neutral state. As a result, in Swiss society and schools, reflections and debates about that time and especially about the Holocaust have been very different from the public debates in Germany or

T. Schlag $(\bowtie)$

Theologisches Seminar, University of Zurich, Kirchgasse 9, 8001 Zurich, Switzerland

e-mail: Thomas.Schlag@theol.uzh.ch

O. Wäckerlig

University of Zurich, Zurich, Switzerland

e-mail: oliver.waeckerlig@access.uzh.ch 
Austria, for example. Especially since the Bergier Report (Heimberg 2002), Switzerland has become more aware of its role and involvement in the political events during the Nazi era, including the question of the country's own involvement in this unique and massive violation of fundamental human rights and the destruction of the idea of humanity. The questions levelled at Switzerland regarding the dormant Swiss bank accounts of Nazi victims sparked a wholesale questioning into the economic facts of the Holocaust and the political forces and interests behind it. Therefore, in recent years sensitivity regarding the former political role of Switzerland has increased significantly. But one question remains open in public opinion: should Switzerland's specific role during that time be addressed more intensely? On this topic we see a wide range of attitudes regarding Switzerland's role in Europe's history and political challenges; some see that this European history as far away from their own national and current reality, while others see it as nearby.

On the other hand, because of its specific role during the twentieth century, Switzerland has become an important place for worldwide debates on human rights, e.g. in connection with the International Red Cross and various United Nations institutions such as the offices of the United Nations High Commissioner for Refugees (UNHCR) and or for Human Rights (OHCHR), located in Geneva. But bearing in mind certain current political movements, it has to be asked how influential this international political engagement is in dealing with the national dimension of human rights, e.g. in relation to the field of migration policy and the phenomena of discrimination and racism within Swiss society.

While Switzerland enjoys a solid reputation for championing human rights on the international stage, within the country itself more efforts must be made to adjust to the international standards of human rights. For example, Amnesty International regularly claims that Switzerland could improve its promotion of rights for women and migrants. Delegates from the UN Human Rights Council comment about the "xenophobic climate" in the country. Meanwhile, in 2005, at the opening session of an Organisation for Security and Cooperation in Europe (OSCE) Conference in Cordoba, Spain, the Swiss delegation (2005) stated that "a latent breeding ground for hatred still appears to exist" (p. 1). Current political movements such as the anti-minaret initiative deliberately play on emotions and prejudices. One of the more glaring problems with promoting human rights in Switzerland is the absence, thus far, of a national body to co-ordinate efforts between federal authorities and cantonal governments. For example, the canton of Geneva has a human rights office, but others do not, and inconsistencies arise in the way that international treaties on human rights are enforced throughout the country.

Within the academic community, at least three institutions are very active in responding to questions about human rights. First, in 1998, the UNESCO Chair in Human Rights and Democracy, now occupied by Professor Patrice Meyer-Bisch, was established at the University of Fribourg. Along with L'Institut interdisciplinaire d'éthique et des droits de l'homme (IIEDH), it promotes an integrated system of research, training, and information and documentation activities in the areas of human rights and democracy. Second, the International Human Rights Forum Lucerne (IHRF), established in 2004 and directed by Peter and Thomas Kirchschläger, is an annual program of the Centre for Human Rights Education (ZMRB) at the Central Switzerland University for Teacher Education at Lucerne (PHZ Lucerne). It aims to support and develop the debate on human rights especially by organising a large annual international forum.

Third, the Kompetenzzentrum für Menschenrechte, at the University of Zurich, was established in 2009 and is coordinated by Christine Kaufmann and Hans-Peter Burkhard. It was conceived to inform actors in the business and political sectors, as well as the public, about human rights and to provide appropriate educational materials. 
In addition, plans for a new national human rights institution are currently underway to help cantons and the confederacy to enforce a common national perspective, not only on current political debates on human rights, but also with regard to Swiss history during the dark events of the twentieth century.

An important contribution to improving sensitivity about the violation and destruction of human rights is the annual commemoration of the fatal history of the victims itself. This was first held in Switzerland on 27 January, 2004, following a decision issued in June 2003 by the Swiss Conference of Cantonal Ministers of Education (German acronym: EDK). This followed a decision on 18 October, 2002 by the European Ministers of Education at the Council of Europe to set a "Day of Remembrance of the Holocaust and for the prevention of crimes against humanity" in the 48 states that had signed the European Cultural Convention.

The EDK made the decision to retain 27 January as Holocaust Remembrance Day in Swiss schools. Not only would this remembrance day be observed annually on that date; in addition, schools should teach pupils about the remembrance in order to prevent crimes against humanity such as the Holocaust. The day would also be used to teach pupils about genocides that have affected twentieth century European history and to reflect on human rights and tolerance as well as interreligious and intercultural dialogue. Then, on 1 November, 2005, the United Nations decided to institute an "International Day of Commemoration in memory of the victims of the Holocaust".

In November 2004, a widely acknowledged exhibition, Histoire et mémoire: la Suisse pendant la Seconde Guerre Mondiale, opened at the Swiss National Museum at Château de Prangins. It displayed the findings of an international commission that had investigated Switzerland's attitude towards the Nazi regime and also the testimonies of more than 500 Swiss citizens about their lives during World War II. Teaching materials were developed to supplement the debate and were made available during the exhibition (Fink and Heimberg 2005).

In 2008, the Swiss Department of Public Information marked Holocaust Remembrance Day with the exhibition Carl Lutz and the Legendary Glass House in Budapest, in the visitors' lobby of the United Nations in New York; it focused on attempts to save Jews from certain death by the Nazis during the war. This exhibition was co-sponsored by the Carl Lutz Foundation and the Permanent Missions of Switzerland and Hungary. Carl Lutz, the Swiss Vice Consul in Budapest, had issued certificates of emigration to place tens of thousands of Jews under Swiss protection.

However, it should be noted that there is no national Holocaust memorial or museum in Switzerland, nor does the country have an institute or museum for war documentation. Nevertheless, the Swiss National Museum in Zurich has integrated components of the Independent Commission of Experts on Switzerland in World War II. Moreover, an Archive for Contemporary History at the Swiss Federal Institute of Technology (ETH) in Zurich focuses on various aspects of the history of World War II and on Holocaust remembrance and also includes the Centre for Jewish Contemporary History (see www.afz.ethz.ch/ fsdokustellen.html), which has been-among other institutions-organizing events on 27 January for several years now (ITF n.d.).

An important step was taken in December 2004, when Switzerland became a formal member of the Task Force for International Cooperation on Holocaust Education, Remembrance and Research (ITF), which was initiated in 1998. The general purpose of the ITF is to get political and social leaders to see the need for, and support Holocaust education, remembrance, and research both nationally and internationally. The Swiss national delegation is always headed by a representative of the Federal Department of Foreign Affairs. 
A national ITF support group was created in 2004, composed of some 20 institutions and individuals, including the EDK, The Federal Commission against Racism (FCR), and teachers, as well as members of NGOs and other institutions.

In addition, a growing number of non-governmental initiatives in Switzerland are helping to develop the scope of Holocaust education and to support human rights education projects. Here, we describe a few to highlight the increasing opportunities to encourage schools to develop this field as part of their school culture.

First, an impressive initiative, the Kontaktstelle für Überlebende des Holocaust (hirsch@cyberlink.ch), is engaged in remembrance work as well as fighting the antiSemitism present in Swiss society today. Gábor Hirsch, one of the few survivors of a Jewish family from Hungary, established this meeting group of Holocaust survivors in Zurich; each year on 27 January he organises a commemoration ceremony. TAMACH (www.tamach.ch) is a psychosocial outreach clinic for survivors of the Holocaust and their relatives in Switzerland and also organises large conferences on these issues.

Founded in 1990, the Geneva-based Coordination intercommunautaire contre l'antisémitisme et la diffamation (CICAD, www.cicad.ch) opposes all forms of anti-Semitism, supports efforts to teach the history of anti-Semitism and the Shoah, and observes Swiss laws against racism. For example, it has encouraged the education departments of each canton to provide their schools with a booklet on Auschwitz-Birkenau by the French historian Sabine Zeitoun; so far more than 15,000 copies have been distributed. The ANNE FRANK-Fonds (www.annefrank.ch/) contributes to better understanding among religions and facilitates international contacts between young people. The Stiftung für Erziehung zur Toleranz (www.set-toleranz.ch) helps to develop educational materials and supports public events for encouraging tolerance towards minorities. Another foundation, the Stiftung gegen Rassismus und Antisemitismus (www.gra.ch/) works with various religious groups to support people who have made outstanding contributions in the fight against racism and anti-Semitism. The Internationale Liga gegen Rassismus und Antisemitismus (www.licra.ch/) aims to sensitise and inform the Swiss public, to develop a more peaceful society. Each year since 2008, on 27 January, the Dr. Bigler/Bergheimer prize (www.biglerpreis.ch) has been awarded to pupils whose work and projects deal with the reasons and consequences of the Holocaust, anti-Semitism or racism. Also important and very active in this context is the Schweizerischer Israelitischer Gemeindebund (www.swissjews.org), which offers schools the travelling exhibition Der Gelbe Stern. Having surveyed the current political situation and the broad variety of organisations, we now examine Swiss educational policies focusing on that thematic field.

\section{Swiss educational policies on Holocaust remembrance and human rights education}

The education system

In the Swiss education system, responsibilities for education are distributed between the confederation, the cantons, and the municipalities, but the cantons are mainly responsible for educational services from nursery school up to university. As a result, education in Switzerland varies significantly between the cantons with regard to the subjects studied, and the duration of their courses. Still, what results from this situation is not a strict separation of responsibilities but rather a growing sense of co-operation among the confederation, the cantons, and the municipalities. 
In Switzerland, education is compulsory for 9 years and consists of primary and lower secondary education (secondary I). Depending on the canton, primary education lasts from 4 to 6 years, and lower secondary education from 3 to 5 years. Upper secondary education (secondary II) is not compulsory and lasts either 3 or 4 years. The two main types of upper secondary schools are academic (Maturitätsschulen) and vocational (Berufsfachschulen). The academic schools prepare students to enter university and teacher training colleges; the vocational schools prepare them for a wide range of occupations and higher vocational schools (Höhere Fachschulen) as well as universities of applied sciences (for students who also pursue the professional baccalaureate).

A main thrust of educational reform in Switzerland, which also has deep implications for a common Holocaust education and human rights education, is harmonisation. This is an issue because differences in the cantonal educational systems can create considerable barriers to a common strategy of civic education within the country. A key here is the determination to reset the duration of each level of education and the specific objectives pupils should attain by the end of each level. This is the focus of the HarmoS-project led by the EDK. If the agreement were to be accepted-which is not certain-the cantons would be able to begin taking steps to harmonise their cantonal structures and objectives concerning compulsory education, as well as education on the Holocaust and human rights.

An important legal basis for the question of Holocaust and human rights education is the statement in the confederation's constitution (1999) that "children and adolescents shall be encouraged in their development into independent and socially responsible individuals and shall be supported in their social, cultural and political integration" (article 41, paragraph 1).

\section{Political and citizenship education in Switzerland}

Thus far Switzerland has not had one common curriculum for the whole country. The curriculum includes a variety of different cantonal educational programmes and civic education has not been a specific school subject, although the Holocaust is an issue and topic in the subjects of history, German, French, Italian, and religious education. In fact, various indicators suggest that the political, civic, and citizenship education in Swiss schools might not be satisfactory and that the schools lack not only a common strategy but also any attempt to broach these issues adequately. Looking generally at the wider field of civic education, it must be said that political instruction in Switzerland is treated as a rather minor issue within the range of school subjects, although education for democracy is one of the most central concerns of the school and the state.

Oser and Reichenbach (2000, pp. 7ff) have shown that up to the 7th grade, no explicit and intentional political instruction is offered. Hence, school-based efforts to socialise students about politics and civic education have no equivalent in the curriculum and are thus not institutionalized in the sense of a specific teaching subject. While instruction about politics was rather feared 20 years ago, now it seems to rather elicit general apathy. To a large extent, practical political and economic thinking have displaced the emotional appeal of democratic upbringing and educational ideals. Even worse, when the higher education entrance examination was reformed in 1995, the subject of history was one of the "losers", along with some other subjects. Oser and Reichenbach describe the problem: the various, and sometimes equally desirable, objectives of political instruction require different approaches and apparently cannot be achieved at the same time. Therefore they conclude that the insoluble dispute between an action orientation and a focus on knowledge of institutions, and between political instruction, or between various didactic approaches, does not merely express a shortage of resources. Another indicator that civic education has 
been made less significant is the fact that it is rarely included during the period of compulsory schooling, and pupils' achievements and progress in it are rarely defined or tested.

As this analysis shows, Switzerland does not have a clear well-established concept of civic and citizenship education. For a deeply rooted participative democracy, this is a problematic, if not dramatic, finding (see also Biedermann et al. 2007; Oser 2005; Oser and Biedermann 2003; Torney-Purta et al. 2001). Not surprisingly, a report on Education for Democratic Citizenship (EDC) policy-making in Western Europe, part of the Council of Europe's All-European Study on the topic, notes that EDC policy in Switzerland is complicated by the nature of the system of 26 cantonal governmental and educational structures (Kerr 2004).

Holocaust education and human rights education

Although Switzerland as a whole lacks a common curriculum or a common school subject called civic education, the Swiss government has made several decisions and initiatives in recent years, such as the ITF mentioned above. These have led to a stronger educational policy on questions of Holocaust education, and also in connection with human rights education. Therefore, more than ever before, teachers and pupils now acknowledge this era in European history as something that not only happened far away from their country but that has also influenced Swiss history in the twentieth century and the country's development since the war.

Recently, Switzerland's Department of Foreign Affairs wrote a report, with the participation of a national International Task Force support group including members of many NGOs (ITF 2007). This report illustrates the situation very clearly. In what follows, we summarize the statements in this report, although it must be said that given the current educational situation, some of these points have yet to be put into practice.

Although the Holocaust is a mandatory subject in Swiss schools, no specific curriculum is devoted to Holocaust education in Swiss schools. So the Holocaust and Holocaust remembrance are not taught as a distinctive and separate topic within school curricula, but as a part of history teaching and civic education. And, as mentioned above, aspects of the Holocaust are also addressed in other subjects.

The cantonal curricula provide guidelines and define goals for teaching Holocaust remembrance (the information that follows is also available on the ITF webpage: www.holocausttaskforce.org/education). For grades 1 through 9, these goals are defined as (1) identifying situations and historical periods; (2) analysing the evolution and alterations within collective organisations of individuals; and (3) grasping the complexity of a decision-making process.

The teaching of Holocaust remembrance is likewise oriented toward the goals of civic and citizen education, aiming to help students become active and responsible citizens. In this context, Holocaust education focuses on helping students know and be aware of the historical facts. Compulsory school (grades 1-9) provides students with 470-500 lessons in history and civic education. At a higher level (gymnasium/lycée and vocational training), the teaching of Holocaust remembrance contributes to the prevention of violence, by aiming to analyse, understand and prevent the causes and forms of violence, racism, xenophobia, and anti-Semitism. The teaching methods are more interactive; they insist that students learn to respect human rights, as well as other people's values, and they promote interaction, solidarity, and mutual understanding. In this respect, competences are just as important as knowledge. At secondary level II (vocational school and high school), students examine and discuss Nazi theories and extermination mechanisms and study fascist 
movements. This teaching takes place in every canton without exception, regardless of the various cantonal study plans.

All over Switzerland teachers have a choice of professional training and continuing education, where they can take courses with titles like Preparing Holocaust Remembrance Day or Racism at School. The main topics of Holocaust Remembrance Day, beyond, of course, the remembrance of the Holocaust, are the genocides that marked European history throughout the twentieth century. In close connection to the topic of human rights, students should reflect on these rights, and they should be linked with questions of tolerance and interreligious and intercultural dialogue. At secondary level II, 10-20\% of the entire teaching time is dedicated to science and humanities: history, geography, civic education, human rights, etc. This is when Holocaust remembrance teaching also takes place.

As a result, there is undoubtedly a growing sense of a need for Holocaust education also in connection with human rights education, although further concrete implementations are needed. Wisard (2009) pointed to significant developments in Holocaust education over the past 10 years, but also remarked on the important task of embedding historical and autobiographical material in the curriculum, both pedagogically and didactically. During a recent international conference in Nuremberg on Holocaust Education, Remembrance and Research, Monique Eckmann, a professor at the Geneva School of Social Work, and a member of the Swiss delegation to the Task Force for International Cooperation on Holocaust Education, Remembrance and Research, presented her idea of Holocaust education as a human rights tool through projects that aimed to connect past and present, historical learning and current discrimination. In this respect, a key idea is that collective memories are of that past, as only that kind of historical self-reflection can lead to a real Citoyenneté or citizenship (Eckmann 2008; see also Eckmann and Eser Davolio 2003).

Until recently teachers have not easily found good quality material on these topics. Over the last few years, however, a remarkable number of publications for teaching and discussing these issues has been released. These materials describe Swiss history during the years 1933-1945 (Furrer et al. 2008; Gautschi and Meyer 2001; Heimberg 2002), with a focus on the dramatic events in Switzerland (Kosmala and Ludewig-Kedmi 2003; Pruschy and Antowiewiecz 2007; Wisard 2008), and on aspects of Holocaust remembrance (Beyeler et al. 2001; Bonhage et al. 2006; Graber et al. 2009); they also connect with the perspective of current violations of human rights (Eckmann and Fleury 2005).

Some specific materials have also been published recently in different cantons: in Lucerne the Holocaust Gedenktag (www.holocaust.edulu.ch), in the French-speaking cantons Journée de la mémoire (Groupe des didactiques 2006, www.didactique-histoire.net) and in Ticino I fascismi e la seconda guerra mondiale (www.atistoria.ch/atis).

In addition, digital information centres provide more material for detailed planning of certain topics and lessons. Examples are Histomat: Automat des Vereins Schweizerischer Geschichtslehrerinnen und-lehrer (www.histomat.ch/); the History Helpline (www. historyhelpline.ch), an internet platform from the University of Education and Social Work in Basel; Schulprojekte gegen Rassismus (www.projektegegenrassismus.ch), which contains school projects in the context of anti-racist education and education for human rights; e.media: le portail romand de l'education aux medias (www.e-media.ch), which contains teaching materials; and finally the Informations-und Dokumentationszentrum (IDES) of the Swiss Conference of Cantonal Ministers of Education (www.ides.ch). Also, the Swiss Education Server SES is a project of the cooperative called educa.ch; it consists of the information platform www.educa.ch and the Community of Education www.educanet2.ch. 
In connection, it should be mentioned that in 2001 the Swiss Federal Council set up the Fonds Projekte gegen Rassismus und für die Menschenrechte (www.edi.admin.ch/frb/ 00645/) to establish a clear and sustainable example against racism, anti-Semitism, and xenophobia. The Fonds für Schulprojekte gegen Rassismus und für Menschenrechte (www.globaleducation.ch) supports an education that enables children to become responsible citizens in a globalised world.

Of course, young people in Switzerland do not have the opportunity to examine Holocaust sites in their own country. Nevertheless, remembrance takes place in various ways. Some schools invite survivors or other witnesses to tell their stories. School groups do visit relevant sites, such as synagogues and Jewish cemeteries. It is not unusual for Swiss classes to go for visits, e.g. to Auschwitz-Birkenau or other former concentration camps or commemoration sites in Germany. Sensitivity regarding the specific refugee history of Switzerland is also increasing. This is because the major topic connecting Switzerland's national history and the Holocaust in teaching material has been the refugee policy, i.e. the admission into Switzerland of several thousand Jewish refugees and the turning away of others. Here we should mention the interesting narrative history project called L'histoire c'est moi: 555 Versionen der Schweizer Geschichte 1939-1945 (www.archimob.ch) about Switzerland during World War II.

Several recent documentary films deal with the persecution of Jews from a Swiss perspective. For example, Aus Galizien in den Aargau: Wege eines jüdischen Europäers im 20. Jahrhundert (2007) by Peter and Susanne Scheiner, describes the former Ukrainian Jewish immigrant Jerzy Czarnecki in Switzerland. The Glass House (2005), by Enrico Pasotti and Aldo Sofia, describes Carl Lutz, the Swiss vice consul in Hungary, who gave letters of protection to the persecuted Jews who asked for his help and obtained extraterritoriality for a glass factory, the Glass House, where he housed Jews to protect them from the SS and the Hungarian Arrowed Cross. Finally, Un ilot dans la tempête (2005), by Neus Viala, is about Jewish children saved by courageous individuals of the Swiss Red Cross in France.

The role and importance of religious education as Holocaust and human rights education

Because Holocaust education and human rights education are now being more and more included as elements of Swiss educational policy, it is also important to reflect on the potential of religious education to contribute to these pedagogical innovations. Religion can be acknowledged as an important resource for understanding not only one's own individual identity but also the collective patterns of history and culture. In that sense, religion should not primarily be seen as a threat to the pluralistic society but as a civilizing force in addition to the moral and political resources for political and citizenship education. Therefore religious and interreligious education in the specific perspective of Holocaust and human rights education can and should be seen as a natural field of this work and also an important contribution to general education (Schlag 2004).

In that respect, noticeable tendencies within the current academic discourse aim to develop educational standards for religious education in a clearly political perspective, of course in close interdisciplinary co-operation with the pedagogy and civic education on politics (Grümme 2009; Grümme and Sander 2008; Schlag 2010). Therefore, intensive theoretical work is being done on the question of a public religious pedagogy and the opportunities for an interreligious pedagogy. 
The role and importance of religious education in Swiss schools also depends greatly on the cantonal historical traditions and the school system. At present more and more cantons are replacing traditional confessional education with an obligatory subject in the sense of a "religious education for all" (Schlag 2009). One major reason for these new educational initiatives is the fact that Swiss schools find themselves in a more and more multicultural and multi-religious situation, dealing with significant cultural and religious frictions among the pupils in Swiss society as well as in daily school life. Therefore, religion is seen as an important factor in individual and school life and one that can be estimated and developed as an integrating factor for daily school life. For example in the Canton of Zurich the main task of the new school subject Religion and Culture is for young people to gain competence in dealing with religious questions and traditions in four ways: (1) become aware of the religious dimension of life; (2) know and understand the main aspects of the five world religions and their cultural traditions; (3) Become able to orient themselves by acknowledging the importance of these religions and their values and norms; and (4) become able to understand and tolerate others and respect their religious and life habits (see Bildungsdirektion 2008, 14). Young people should learn to see and understand the world and themselves not only from their own perspective but from the perspective of others. This ability to change perspective is seen as the decisive prerequisite for acknowledging human beings who have been socialised in different religious and cultural ways, and for being able to respect them, and engage in dialogue with them.

This situation brings with it an approach to teaching about the different aspects, roots, and traditions as well as the cultural manifestations, of the most important world religions but without valuing or even rating them. Therefore the teaching principles require plurality: what are constructive ways to deal with different claims of truth, authenticity, and context in the sense of integrating "original" representatives of the different religions into the educational process? The main teaching principles are neutrality and equality of religions and respect and openness toward all religious convictions and traditions. Under the umbrella of "religious education for all", Holocaust and human rights education can be seen as vital perspectives and topics of this new subject. Although the time is very short-only two lessons in grade 7 once a week and one lesson in class 8 once a week-both perspectives should be seen as a fairly important basis for the schedule, which is also expected to work co-operatively with other subjects or projects in the school context.

Having examined the Swiss educational policies on Holocaust remembrance and human rights education, we find, on the one hand, a growing interest for these thematic fields. On the other hand, the impacts and consequences of these educational measures are not clear so far. Therefore in the following section we will list some future research directions and questions, along with needed educational policies and future work.

\section{Perspectives}

Research interests and questions

Having examined the fields of Holocaust and human rights education in Switzerland, we see a significant lack of data on the real impacts and effects these educational measures have had so far. Thus, more empirical research is needed on the educational effects of these efforts, especially in order to develop teaching material and improve teacher education in these fields. We see several directions for this research. 
First, it is necessary to clearly distinguish the past and current perspectives on the two topics, without mixing them together. This is because it is not at all clear whether and how historical consciousness and remembrance have a positive influence on adolescents' identity formation and on their gaining a positive attitude and approach to an individual understanding of human rights. Moreover, do they help prevent human rights violations?

Second, open research questions must be identified and examined, especially with regard to the correlation between historic remembrance and current political questions, as it is not at all clear whether teaching one subject has real consequences for the other.

Third, what do young people know about the Holocaust and the Third Reich, and how much do they understand human rights? And, how is this knowledge connected to a disposition to engage against violations of human rights, anti-Semitism, and populism in the shape of right-wing extremism? These issues should also be connected with their understanding of national identity and their perception of recent European history and the current challenges of human rights and migration.

For all these reasons, intensive research is needed to determine how Holocaust education, conducted in connection with human rights education, can be assessed as successful. How can such education avoid being overly emotional but still be sustainable and lead adolescents to orient themselves more deeply in their individual and social conduct throughout life?

The role of religious education has to be examined specifically, because religion can be both positive and problematic; it can both enforce and motivate sensitivity towards human rights and destroy mutual understanding and empathy. Following on from this understanding, both quantitative and qualitative research must be developed in the medium term so that religious educators can create appropriate approaches to Holocaust and human rights education.

Therefore, a large quantitative survey is currently underway of pupils aged 15 and 16 at different levels of education (Gymnasium and Sekundarschule A, B, and C). The focus is on students in 9th class in the Canton of Zurich, in order to reach pupils at the end of their compulsory education. A sample of about 250 pupils has been drawn from that population, and a first pre-test was initiated early in 2009.

The research project addresses various aspects of knowledge about the Holocaust: i.e. the historical facts about "Auschwitz" and the responsibility for concentration camps, their occupants, and the reasons for deportation. In connection with commemorating this part of Swiss history, the pupils are asked about the primary sources of their knowledge (e.g. films, media, school lessons, parents, visiting sites, etc.). The study also attempts to grasp, what significance remembrance has for their understanding of and ways of dealing with human rights in order to anticipate both outrage and increased xenophobia. Thus the pupils are asked about their knowledge of human rights: various types of human rights and their meaning, their historic and philosophical foundations, associations with current violations of human rights (e.g. torture, "Guantanamo", etc.), their estimation of the human rights situation in Switzerland, and their own personal feelings about the current violations. In connection with this they are also asked about the primary sources of their knowledge of human rights. To better understand the possible connection between Holocaust remembrance and the individual understanding of human rights they are also asked if and in which sense they identify analogies between the historical facts of the Holocaust and the actual question of human rights violations.

In addition, the quantitative study examines the dimensions and impact of religious education as a source for political sensitivity and understanding in order to survey its potential role in Holocaust education with implications for human rights education. 
Here the pupils are asked what they have learned in religious education about the Holocaust and human rights and to what extent this was helpful for them. That is, what are the religious and theological motives behind anti-Semitism and what were the roles of the churches or aspects of religiously motivated resistance? The pupils are also asked about their religious backgrounds to examine the possible influence that religious attitudes have on questions of human rights and the importance of religious self-understanding and collective identity for a culture of remembrance.

In analyzing the results we plan to consider pupils' answers at the various school levels as well as their family and possible migration backgrounds. Thus far the empirical data base is rather small, but we can already sketch some future tasks.

Tasks for educational policies and future work

We can already name some major standards for a future Holocaust education in connection with human rights education as a heuristic perspective for interpreting our results and developing further teaching material.

First, there has to be a movement towards remembrance work and away from "the obligation to remember", which deals with the extremes, with concentration and extermination camps and crematories. The emotional impact can be very powerful, but do students clearly hear the historical and political reasons why this historically genuine and devastating violation of human rights occurred? It is crucial that students move beyond being "merely" morally outraged, and are helped to grasp the full political backgrounds of these events.

Therefore, we believe that the framework of future Holocaust education and human rights education in Switzerland must be shaped in light of the idea and principles of an education for democratic citizenship, based on the fundamental principles of human rights, pluralist democracy, and the rule of law. Both Holocaust education and human rights education must refer to this idea of citizenship education by shaping their own profiles in the wider perspective of preparing young people to participate actively in a democratic society. This means strengthening civil society by helping make its citizens informed and knowledgeable, and also endowing them with democratic skills to prevent them from repeating the dark history. It follows that Holocaust education can give pupils a range of concrete ideas about how to act freely in an autonomous and creative way, to think critically, to be aware of their rights and responsibilities, and to participate in peaceful dialogue, deliberation, and negotiation. Thus, such citizenship education must be seen as the most appropriate perspective to fight violence, xenophobia, racism, aggressive nationalism and intolerance. Here the ITF guidelines on the educational tasks and standards are valuable (www.educa.ch/dyn/171399.asp).

In terms of pedagogy, it is important to give equal importance to knowledge, values, and attitudes and to the capacity to act and participate in a democratic context in both school and society so pupils can learn how to take on roles as active citizens. The curriculum should be designed so that it includes cognitive and/or knowledge-imparting activities as well as action-oriented ones. Political and citizenship education should be conceived not only as a subject but also as a teaching principle. It must not be restricted only to a narrow understanding of politics and the state but must also elucidate economic and social relationships. Moreover, it must not dedicate itself to the-probably impractical-ideal of value neutrality but rather to the principle of embracing controversial discussion and avoiding indoctrination (Klöti and Risi 1991, pp. 81ff; Hauler 1995, p. 134). 
The Committee of Ministers of the European Council (2002) pointed out that education for democratic citizenship can be seen as embracing any formal, non-formal, or informal educational activity, enabling any individual to act throughout his or her life as an active and responsible citizen in the framework of his or her rights and responsibilities in a democratic society. Thus education is a factor for social cohesion, mutual understanding, intercultural education and inter-religious dialogue, and solidarity; it helps to promote the principle of equality between men and women, encourages the establishment of harmonious and peaceful relations within and among peoples, and defends and develops democratic society and culture.

Within that perspective, in Switzerland, Holocaust education and human rights education need to be pursued more actively than has so far been the case. Therefore, it is also important to make education for democratic citizenship a priority objective of educational policy-making and reforms by encouraging and supporting initiatives to promote such civic education within the whole state, its cantons, and its schools.

Although it is clear that all of Switzerland's school curricula include cross-disciplinary skills, in each subject area the profile of education for democratic citizenship must be raised in order to trigger the reinforcement that the cross-disciplinary approach can provide. The only way to achieve this shift is for curriculum planners, training providers, and textbook publishers to work together more intensively than they have so far.

This opens up the possibility-if not the need - to connect the perspectives of political and religious education. Given Switzerland's situation as an increasingly multi-ethnic and multi-religious country, Holocaust and human rights education will encounter new difficulties. Pedagogical tools have yet to be devised and created that can help pupils with nonEuropean backgrounds and various religious and cultural identities and family histories to understand the reality of the Holocaust.

Bîrzea (2000, p. 17) has summarized the aims and goals of citizenship education in the form of three key questions: What values and skills will people need to be fully-fledged citizens in Europe in the twenty-first century? How can these values and skills be developed? And how do we convey them to others, whether children, young persons, or adults? These goals and aims have to be adopted to shape concrete initiatives and teaching models (for both pupils and teachers) in the light of Holocaust education and human rights education in Switzerland.

In this light, Swiss participants and institutions should involve themselves more than ever with other European initiatives and also harmonise their local, cantonal, and national initiatives to encourage synergies. Greater efforts have to be made to set up strong partnerships between schools, youth organisations, and adult training centres as well as with academic institutions that provide teacher training and conduct international interdisciplinary research.

Having looked at the political situation, the initiatives currently underway around Holocaust and human rights education, and the situation in schools, it is now possible to draw some conclusions on how to move the situation forward in Switzerland. Switzerland cannot see itself and its history as separate from the European developments within the twentieth century. This country is a vital part of Europe and therefore has a deep responsibility to contribute seriously to a more peaceful Europe. Even if the Swiss people might not have been actively involved in the activities of World War II and the cruelties of the Holocaust, they must face the question of their own responsibility for the past and for a more peaceful European future. Therefore Holocaust education and human rights education must become important cornerstones of Swiss educational policy, motivating teachers, pupils, and the whole society to gain knowledge about the dark side of European history, to 
enhance sensitivity to the violations of "the other" in current politics, and to acquire greater competence to bring democratic citizenship to real life.

\section{References}

Beyeler, R., Treu, L., \& Zimmermann, M. (2001). Achtung Verachtung: Unterrichtsmaterialien für die Oberstufe zu Rassismus, Nationalsozialismus, Rechtextremismus und Reaktionen von Staat und Gesellschaft [Attention, contempt: Teaching materials for the advanced level about racism, National Socialism, right-wing extremism, and reactions of state and society]. Zurich/Berne: Verlag Pestalozzianum.

Biedermann, H., Oser, F., \& Quesel, C. (Eds.). (2007). Vom Gelingen und Scheitern Politischer Bildung: Studien und Entwürfe [On the success and failure of political education: Studies and concepts]. Zurich, Chur: Rüegger.

Bildungsdirektion Kanton Zürich (Eds.). (2008). Religion und Kultur. Ergänzung zum Lehrplan für die Volksschule des Kantons Zürich [Religion and culture. Additions to the curriculum for secondary schools in the Canton of Zurich]. Zurich: Lehrmittelverlag des Kantons Zürich.

Bîrzea, C. (2000). Education for democratic citizenship: A lifelong learning perspective. Doc. DGIV/EDU/ CIT 21. Strasbourg: Council of Europe.

Bonhage, B., Gautschi, P., Hodel, J., \& Spuhler, G. (2006). Hinschauen und Nachfragen: Die Schweiz und die Zeit des Nationalsozialismus im Licht aktueller Fragen [Looking and asking: Switzerland and the era of National Socialism in view of current questions]. Zurich: Lehrmittelverlag des Kantons Zürich.

Committee of Ministers (2002). Recommendation 12 of the Committee of Ministers to member states on education for democratic citizenship. Adopted by the Committee of Ministers on 16 October 2002 at the 812th meeting of the Ministers' Deputies. Doc. DGIV/EDU/CIT 38. Strasbourg: Council of Europe.

Confederation of Switzerland (1999). Federal constitution. http://www.admin.ch/ch/e/rs/1/101.en.pdf.

Eckmann, M. (2008). Welche historischen Bezüge braucht eine Bildung gegen Diskriminierung? [What historical approach should education take to counter discrimination?] Presentation at the international conference: The right that makes us human: Human rights as an answer to historical and current injustice, Nuremberg, 20-22 November, 2008. english.konferenz-nuernberg08.de/Eckmann.pdf.

Eckmann, M., \& Eser Davolio, M. (2003). Rassismus angehen statt übergehen: Theorie und Praxisanleitung für Schule, Jugendarbeit und Erwachsenenbildung [Fighting against racism instead of ignoring it: Theory and practical instruction for school, youth work, and adult education]. Zurich: Verlag Pestalozzianum.

Eckmann, M., \& Fleury, M. (2005). Racismes et citoyenneté: Un outil pour la réflexion et l'action [Racism and citizenship: A tool for reflection and action]. Geneva: éditions ies.

Fink, N., \& Heimberg, C. (2005). Histoire et mémoire: La Suisse pendant la Seconde Guerre mondiale. Dossier pédagogique accompagnant l'exposition du Musée National Suisse [History and memory: Switzerland during the 2nd World War]. Pedagogical dossier accompanying the exposition at the Swiss National Museum, Château de Prangins, 5 November 2004-30 January 2005. Prangins: Swiss National Museum.

Furrer, M., Messmer, K., Weder, B., \& Ziegler, B. (2008). Die Schweiz im kurzen 20. Jahrhundert 1914 bis 1989-mit Blick auf die Gegenwart. Studienbuch der Pädagogischen Hochschulen Zürich und Zentralschweiz Luzern [Switzerland during the 20th century 1914-1989-with a look toward the present]. Zurich: Pestalozzianum.

Gautschi, P., \& Meyer, H. (2001). Vergessen oder Erinnern? Völkermord in Geschichte und Gegenwart [Forgetting or remembering? Genocide in history and present]. Zurich: Lehrmittelverlag Zürich.

Graber, S., Bühlmann, B., \& Müller, M. (2009). Werkmappe Holocaust für den Unterricht. "B-8326. Ein Überlebender des Holocaust" von Nathalie Gelbart [Portfolio of the Holocaust for the lesson "B-8326. A survivor of the Holocaust" by Nathalie Gelbart]. Lucerne: Rex Verlag.

Groupe des didactiques de l'histoire (2006). Journée de la mémoire et de la prévention des crimes contre l'humanité: 27 janvier 2006 [Journal of memory and prevention of crimes against humanity: 27 January, 2006]. www.didactique-histoire.net/article.php3?id_article=55\&var.

Grümme, B. (2009). Religionsunterricht und Politik. Bestandsaufnahme-Grundsatzüberlegungen-Perspektiven für eine politische Dimension des Religionsunterrichts [Religious education and politics. Stocktaking - principle considerations_-prospects for a political dimension of religious education]. Stuttgart: Kohlhammer. 
Grümme, B., \& Sander, W. (2008). Von der "Vergegnung” (Martin Buber) zum Dialog? Das Verhältnis von Religionsdidaktik und Politikdidaktik [From "missing" (Martin Buber) to dialogue: The relationship between religious didactics and civic education]. Theo-Web 7(1), 143-157.

Hauler, A. (1995). Die Schweiz auf dem Weg nach Europa: Politikprobleme und Dilemmata politischer Bildung [Switzerland on the way to Europe: Political problems and dilemmas of civic education]. Bonn: Europa Union Verlag.

Heimberg, C. (2002). Le rapport Bergier à l'usage des élèves: La Suisse, le national-socialisme et la Seconde Guerre mondiale. La question des réfugiés [The Bergier report for use by pupils: Switzerland, National Socialism and the 2nd World War. The question of refugees]. Geneva: Pendo Verlag.

Kerr, D. (2004). Education for democratic citizenship 2001-2004. All-European study on policies for education for democratic citizenship (EDC). Regional study, Western Europe Region. Strasbourg: Council of Europe.

Klöti, U., \& Risi, F.-X. (1991). Politische Bildung Jugendlicher: Bericht über die im Rahmen der Pädagogischen Rekrutenprïfungen 1988 durchgeführte Befragung (Vol. 11) [Civic education of adolescents: Report on the inquiry into the 1988 pedagogical examinations of recruits]. Aarau/Frankfurt am Main: Suhrkamp.

Kosmala, B., \& Ludewig-Kedmi, R. (2003). Verbotene Hilfe: Deutsche Retterinnen und Retter während des Holocaust [Forbidden help: German rescuers during the Holocaust]. Zurich, Berlin: PestalozzianumVerlag and Auer-Verlag.

Oser, F. (2005). Jugend ohne Politik: Muster des Zusammenhangs einzelner Ausprägungen [Youth without politics: Example of the correlation of individual characteristics]. In I. Rickenbacher (Ed.). Demokratie leben-Demokratie lernen (pp. 13-24). Berne: Staatssekretariat für Bildung und Forschung SBF.

Oser, F., \& Biedermann, H. (2003). Jugend ohne Politik: Ergebnisse der IEA Studie zu politischem Wissen, Demokratieverständnis und gesellschaftlichem Engagement von Jugendlichen in der Schweiz im Vergleich mit 27 anderen Ländern [Youth without politics: Results of the IEA study about political knowledge, democratic attitude, and social commitment of adolescents in Switzerland compared to 27 other countries]. Zurich/Chur: Rüegger.

Oser, F., \& Reichenbach, R. (2000). Political/civic education in Switzerland. Final report by Swiss Conference of Cantonal Directors of Education (Schweizerische Konferenz der kantonalen Erziehungsdirektoren [EDK]). In Networking European citizenship education. Online-Reader No.1. Political education in schools and its scientific bases. Contributions and analyses from the European discussion. www.civnet.org/contenidos.php?id_secciones=OA==\&ACTION=TW9zdHJhclVuQ29ud GVuaWRv\&id_contenido=MzA3.

Pruschy, E., \& Antowiewiecz, G. (Eds.). (2007). Survivre et témoigner: Rescapés de la Shoah en Suissel ÜberLebenErzählen. Holocaust-Überlebende in der Schweiz. [Telling about surviving: Holocaust survivors in Switzerland]. Zurich: Pestalozzianum and Les éditions ies.

Schlag, T. (2004). Politische Bildung als Dimension der Religionspädagogik: Ethisch-theologische Überlegungen [Civic education as an aspect of religious education: Ethical-theological considerations]. In F. Schweitzer \& T. Schlag (Eds.). Religionspädagogik im 21. Jahrhundert (pp. 252-265). Gütersloh: Herder.

Schlag, T. (2009). "Reden über Religion": Religionsunterricht in der Schweiz innerhalb der Grenzen der bloßen Vernunft ["Speaking about religion": Religious education in Switzerland within the boundaries of reason alone]. In M. Meyer-Blanck \& S. Schmidt (Eds.). Religion, Rationalität und Bildung (pp. 163-176). Würzburg: Ergon.

Schlag, T. (2010). Horizonte demokratischer Bildung: Evangelische Religionspädagogik in politischer Perspektive [Horizons of democratic education: Protestant religious education in its political perspective]. Freiburg im Breisgau: Herder.

Swiss Delegation (2005). To the Organization for Security and Cooperation in Europe (OSCE) conference on anti-Semitism and other forms of intolerance, Cordoba, 8 and 9 June 2005. Statement at opening session. www.osce.org/documents/cio/2005/06/15007_de.pdf.

Task Force for International Cooperation on Holocaust Education, Remembrance, and Research [ITF] (2007). Country Report on Holocaust Education in Task Force Member Countries: Switzerland. www.holocausttaskforce.org/education/holocaust-education-reports/switzerland-holocaust-educationreport.html.

Task Force for International Cooperation on Holocaust Education, Remembrance, and Research [ITF] (Eds.). (n.d.). Education. Retrieved from www.holocausttaskforce.org/education.

Task force for International Cooperation on Holocaust Education, Remembrance, and Research [ITF] (Eds.). (n.d.). How to teach about the Holocaust in schools. www.holocausttaskforce.org/education/ guidelines-for-teaching/how-to-teach-about-the-holocaust.html. 
Torney-Purta, J., Lehmann, R., Oswald, H., \& Schulz, W. (2001). Citizenship and education in twenty-eight countries: Civic knowledge und engagement at age fourteen. Amsterdam: IEA.

Wisard, F. (2008). Les Justes suisses: Des actes de courage méconnus au temps de la Shoah [The just Swiss: Unknown acts of justice in the time of the Shoah]. Geneva: Coordination intercommunautaire contre l'antisémitisme et la diffamation (CICAD).

Wisard, F. (2009). Holocaust education in Switzerland. Presentation at the 2nd Dr. Bigler/Bergheimer Awards, 27 January, 2009. www.biglerpreis.ch/fileadmin/dateien/pdf/Holocaust_Education_D.pdf.

\section{Author Biographies}

Thomas Schlag (Germany/Switzerland) is a Professor of Practical Theology at the Faculty of Theology, University of Zurich and, since 2009, also at the Protestant Faculty of the University of Tubingen. A Protestant minister since 1996, he studied Protestant Theology and Political Science at the Universities of Tubingen and Munich. He directs the Centre for Church Development at the Faculty of Theology in Zurich. His main fields of research are religious education and church development.

Oliver Wäckerlig (Switzerland) worked in chemical and bioscience research for 10 years before pursuing studies in social sciences. He earned his Bachelor of Arts degree in sociology and religious studies at the University of Zurich, where he is currently completing a master's programme. Currently, he is working on a research project, sponsored by the Swiss National Science Foundation (SNSF), on the minaret conflict in Switzerland. His research interests lie in issues related to nationalism, cultures of remembrance, migration, and Islam in Europe. 